Field-study science classrooms as positive and enjoyable learning environments

Julien M. Zaragoza and Barry J. Fraser( $\square)$

Barry J Fraser

Curtin University

GPO Box U 1987

Perth WA 6845

Australia

Tel: $\quad+61892667896$

Fax: +61 892662503

Email: B.Fraser@curtin.edu.au 


\title{
Field-study science classrooms as positive and enjoyable learning environments
}

\begin{abstract}
We investigated differences between field-study classrooms and traditional science classrooms in terms of the learning environment and students' attitudes to science, as well as the differential effectiveness of field-study classrooms for students differing in sex and English proficiency. A modified version of selected scales from the What Is Happening In this Class? (WIHIC) questionnaire was used to assess the learning environment, whereas students' attitudes were assessed with a shortened version of a scale from the Test of Science Related Attitudes (TOSRA). A sample of 765 grade 5 students from 17 schools responded to the learning environment and attitude scales in terms of both their traditional science classrooms and classrooms at a field-study centre in Florida. Large effect sizes supported the effectiveness of the field-studies classroom in terms of both the learning environment and student attitudes. Relative to the home school science class, the field-study class was considerably more effective for students with limited English proficiency than for native English speakers.
\end{abstract}

Key words: Attitudes; informal science education; learning environments; limited English proficient students; What Is Happening In this Class? (WIHIC)

\section{Introduction}

According to Falk (2001), learning science can occur in two types of learning environments, namely, formal and informal or free-choice. The formal learning environment is considered by most as a classroom setting with an instructor leading and engaging students in a structured lesson. The second type, the informal or freechoice learning environment, is typically associated with museums, zoos and specialised science education centres (Harington 2001). The location for our study, an environmental education centre in Miami, Florida, can be categorised as an informal learning environment. Research suggests that learning can occur outside the 
traditional or formal school setting (Dhingra 2003; Falk and Adelman 2003; Falk and Dierking 2002).

Many researchers, curriculum developers and teachers consider that the most neglected of all the learning environments in science teaching is the outdoor environment (Orion and Hofstein 1994). Research indicates that teachers often avoid the outdoor learning environment because they are not comfortable with the field trip experience (Fido and Gayford 1982; McKenzie, Utgard and Lisowski 1986). Orion, Hofstein, Tamir and Giddings (1997) suggest that, because of the lack of understanding of the outdoors as an effective learning environment, outdoor education is in a neglected state. However, Soper (2009) tentatively suggests that a movement has started to integrate informal education and formal education to benefit learners in science education.

We investigated whether field-study classrooms, emphasising environmentbased and constructivist, hands-on education, could promote positive attitudes and provide a positive learning environment for the study of environmental education for grade 5 students in Miami-Dade County Public Schools, Miami, Florida. The study took place at the Marjory Stoneman Douglas Biscayne Nature Center for Environmental Education (BNCEE) on Key Biscayne, Florida. The study investigated not only whether a field-based classroom could provide a positive learning environment, but also whether students developed positive attitudes towards environmental science. We explored differences in students' perceptions of the learning environment and attitudes between traditional classrooms and field-study classrooms.

This study also focused on two specific populations, females and Limited English Proficient (LEP) learners, and whether the field-study centre was differentially effective for different students according to their sex and English proficiency. Our specific research questions were:

1. Are modified scales from the What Is Happening In this Class? (WIHIC) and Test of Science Related Attitudes (TOSRA) valid and reliable when used with $5^{\text {th }}$ grade students in field-study science classrooms?

2. Are there differences between field-study classes and home school science classes in terms of (a) learning environment and (b) attitudes to science? 
3. In terms of learning environment and attitudes to science, are field-study classes differentially effective for (a) males and females and (b) LEP and nativeEnglish speakers?

Our study is significant within the field of learning environments because very little prior research has investigated the efficacy of informal settings, such as fieldstudy centres, using learning environment criteria. Therefore, another associated contribution of this study is that we modified a frequently-used questionnaire for assessing formal learning environments and cross-validated it with a relatively large sample of students attending informal field-study classes. Finally, our study is unusual in that it investigated the differential effectiveness of field-study classes for different subgroups of students (namely, males vs. females, and LEP vs. native English speakers).

\section{Background}

This section describes the background for this study, including a description of tools used for the assessing the learning environment with the What Is Happening In this Class? (WIHIC) questionnaire and attitudes towards science with the Test of Science Related Attitudes (TOSRA). Brief consideration also is given to Limited English Proficient (LEP) learners and gender issues in science education.

Field of learning environments

Traditionally, most research in education research has focused mainly on student achievement criteria. However, many researchers now evaluate the learning environment to which students are exposed and explore how students feel about the classroom atmosphere (Fraser 2012, 2014). As a result of students' exposure to more favourable learning environments, student achievement and attitudes also are likely to improve according to much prior research (Chionh and Fraser 2009; Fraser and McRobbie 1995). 
Much research has been dedicated to studying students in science and mathematics courses and their responses to their learning environments (Aldridge and Fraser 2008; Fisher and Khine 2006; Fraser 1986, 2012, 2014; Fraser and Walberg 1991; Khine and Fisher 2003). However, there has been little research on how the learning environment can influence the learning, achievement, and attitudes to science among students in multi-disciplinary science courses such as environmental science.

There are many different questionnaires that can be used to evaluate the learning environment and these have been cross-validated and used extensively by researchers throughout the world (Fraser 1998a, 1998b, 2012). The study of learning environments dates back to 1968 when Herbert Walberg and Rudolf Moos independently developed research programs in the USA involving the widely-used Learning Environment Inventory (LEI) (Walberg and Anderson 1968) and the Classroom Environment Scale (CES) (Moos and Trickett 1974). Next, programs of learning environment research sprung up in the Netherlands and Australia. In the Netherlands, Wubbels and colleagues led programmatic research focusing specifically on interactions between students in the classroom and often involving use of the Questionnaire on Teacher Interaction (QTI) (Wubbels and Brekelmans 2005, 2012; Wubbels and Levy 1993). In Australia, Fraser and colleagues also initiated programmatic research which initially focused on student-centred classrooms and use of the Individualised Classroom Environment Questionnaire (ICEQ) (Fraser 1990; Fraser and Butts 1982).

The Science Laboratory Environment Inventory (SLEI) is specifically intended for assessing science laboratory classes at the high school and higher-education levels (Fraser, Giddings and McRobbie 1995; Fraser and McRobbie 1995; Fraser, McRobbie and Giddings 1993; Lightburn and Fraser 2007). Although this instrument appeared potentially useful for our study, there was no separation of lecture and laboratory time at the field-study classroom.

The Constructivist Learning Environment Survey (CLES) enables researchers and teacher-researchers to monitor the development of constructivist approaches to teaching and learning school science and mathematics (Taylor, Fraser and Fisher 1997). The CLES was developed to assist researchers and teachers to assess, reflect, and modify teaching practices consistent with constructivist epistemology (Koh and Fraser 2014; Nix, Fraser and Ledbetter 2005). 
The What Is Happening In this Class? (WIHIC) questionnaire is a combination of scales from a wide range of existing questionnaires and can be used for secondary students. The WIHIC was developed initially by Fraser, Fisher and McRobbie (1996) to measure high-school students' perceptions of their classroom environments. Since its development, the WIHIC has been used to measure the psychosocial aspects of the classroom learning environment in various contexts either without any modifications or after being adapted to suit specific researcher needs (Rickards, den Brok, Bull and Fisher 2003). The WIHIC has consistently been found to be reliable, valid, and useful in numerous studies involving innovative undergraduate science courses, various subject areas, various languages, use of technology in education, and different grade levels in the United States, Canada, Singapore, the United Kingdom, Korea, Australia, Hong Kong, Indonesia, India, South Africa, the United Arab Emerates and Taiwan (Chionh and Fraser 2009; Dorman 2003, 2008; Fraser and Raaflaub 2013; Helding and Fraser 2013; Khoo and Fraser 2008; Kim, Fisher and Fraser 2000; Koul and Fisher 2004; Long and Fraser 2015; Martin-Dunlop and Fraser 2008; Zandvliet and Fraser 2004, 2005). Therefore, a modified version of the WIHIC, containing specific scales suited for our particular research project, was used to assess the learning environment of environmental science field-study classrooms.

Assessing attitudes to science with TOSRA

The promotion of favourable science-related attitudes is considered to be one of the most important aims of science education in many countries (Kind, Jones and Barmby 2007; Osborne, Simon and Collins 2003; Tytler and Osborne 2012). Our study included students' attitudes as an important criterion in assessing the effectiveness of students' experiences at the field study centre. The Test of Science Related Attitudes (TOSRA) was designed to measure seven distinct science-related attitudes among secondary school students (Fraser 1978, 1981). By using selected scales from the TOSRA, researchers can investigate whether students' attitudes and enjoyment in science lessons can be influenced by the learning environment. We selected TOSRA's Enjoyment of Science Lessons scale (Fraser 1981) for our study. Because time constraints, only 7 of the 10 items in the original Enjoyment scale were used. Negatively-worded items found on the original TOSRA scale were omitted or reworded to avoid confusion among students as recommended by Schriesheim et al. (1991). TOSRA has been found to be valid and useful in many studies around the 
world (Fraser, Aldridge and Adolphe 2010; Fraser and Raaflaub 2013; Kim, Fisher and Fraser 2000; Wong and Fraser 1996).

Combining informal and formal education and science education centres and museums (SECSMS)

Science educators have extolled the merits of informal or free-choice settings for learners of all ages (Falk and Dierking 2012). Also researchers such as Soper (2009), Wellington (1990) and Zinicola and Devlin-Scherer (2001) have attempted to combine formal and informal learning environments. Hofstein, Bybee and Legro (1997) attempted to link the two learning styles by using guidelines established by the National Science Education Standards (National Research Council 1996). Bybee (2001) further states that the goal in combining formal and informal learning environments is to achieve scientific literacy. Hofstein and Rosenfeld (1996) suggest that future research into science education should show "how to effectively blend informal and formal learning experiences in order to significantly enhance the learning of science" (p. 107).

One of the major drawbacks of SECSMs is the novelty factor. Learners can be distracted when subjected to a novel environment and can spend too much time adjusting to a new environment and this can direct them away from actual learning (Falk, Martin and Balling 1978; Kubota and Olstad 1991; Martin, Falk and Balling 1981). However, because novelty wears off, some research suggests that students learn more when multiple visits to SECSMs are provided (Balling and Falk 1980; Falk 1983; Falk and Balling 1982; Price and Hein 1991).

The learning environment at the Biscayne Nature Center for Environmental Science (BNCEE) can be considered a hybrid of formal and informal learning environments. Students voluntarily attend a two-day program (informal). Parents have the choice of not allowing their children to participate in the informal program, unlike compulsory attendance in formal education. A structured curriculum is a feature of formal learning environments and, at the BNCEE, there is teacher-led (formal) instruction by six certified teachers and a state-of-the-art laboratory where students engage in hands-on laboratory experiences (formal). The learning at the BNCEE is conducted in all three of the types of learning environment, namely, classroom, laboratory and outdoors, as described by Orion, Hofstein, Tamir and Giddings (1997). The BNCEE can also be considered an informal learning 
environment because it is not recognised as a formal school by any accreditation body, there is no formal assessment, and there are less directly-measured outcomes.

The BNCEE field-study encompasses two days, with different activities being held on each day depending on the availability of time, the size of the group of students, and weather and tide conditions. The main activities include a walk through the hardwood hammock, catching marine organisms in the seagrass beds just off the barrier island, a mangrove forest walk, and a science laboratory activity. When collecting marine organisms, students work in pairs, with one student being given a landing net and the other a bucket. A group of up to 20 students, led by a teacher from the BNCEE staff, go into the waist-deep water off the barrier island of Key Biscayne. Students take turns dragging the net into the seagrass beds where they attempt to catch a myriad of marine organisms, including fish, crabs, echinoderms, algae and shrimp. All organisms are kept in buckets and later brought to the beach, where students divide them into different phyla, from the least to most complex. The teacher then engages the students in a conversation about the different types of organisms, their physiology and their adaptions for survival before the organisms are released back to the seagrass beds and the students return to the centre.

On the second day, two activities are planned. The first is a nature walk through the hardwood hammock (marine coastal forest) when students undertake leafrubbings of the various types of indigenous and exotic plants found in the hammock. The BNCEE teacher also describes the features of the ecosystem and points out the different organisms and their adaptations for survival. The other activity is a two-hour experience in a state-of-the-art laboratory that is equipped with 1750 -gallon salt water aquariums filled with a diversity of native flora and fauna specimens. Students engage in a variety of hands-on, active- and cooperative-learning experiments, observations, data collection and short report writing.

Limited English Proficient (LEP) learners

In our study, we investigated the differential effectiveness of field-study classes for students of differing English-language abilities. Large-scale instructional interventions aimed at promoting achievement and equity in science and literacy for linguistically- and culturally-diverse school students have been undertaken (Cuevas et al. 2005). The science education community has made strides in providing 
opportunities for multicultural and multilingual students (Fradd and Lee 1999; Lee 2002; Rosebery, Warren and Conant 1992; Warren et al. 2001a, 2001b). Learning science is demanding for most students, but particularly challenging for LEP students (Lee and Avalos 2002). In Florida, the State Department of Education uses the term Limited English Proficient (LEP) to refer to students learning English as a new language.

Although most states in the USA require that all elementary LEP students receive the same amount of instructional time as English-proficient students, LEP students are often removed from core content instruction to receive instruction for English language development (Fleishman and Hopstock 1993; Thomas and Collier 2001). Thus, LEP students might not be exposed to science content until they have become English proficient, at which time they are mainstreamed into regular classrooms (Lee and Avalos 2002). Although LEP students might develop general literacy and social language, students who are, or appear to be, English proficient might not be proficient in learning the more complex academic language of science (Cummins 1984, 1986; Scarcella 2003). Therefore, in our study, we investigated the differential effectiveness of field-study classes for LEP learners and native-English speakers.

Gender issues and science education

Over the last 30 years, extensive research has been carried out on gender and education, especially for the subject of science (Baker 2012; Kahle and Lakes 1983; Kelly 1987; Parker, Rennie and Fraser 1996; Rich 2004). Because of the loss of interest in science among girls in school, there is an under-representation of women in occupations in science. Referring to a report by the German Ministry of Education (BMBW), Schwedes (2006) states that, of the girls starting vocational training in 1988, only about $5 \%$ chose a profession in science and engineering (excluding medicine). Baird (1997) notes that women represent only $12 \%$ of working scientists in the United States. Brickhouse (1994) and Shroyer, Backe and Powell (1995) report that many women lack the science skills to enable them to be active members in our ever-growing technological world. Barriers to females' participation and achievement in science including parental values, the masculine image of science, disenfranchising teaching methods, and non-inclusive curriculum materials - are reviewed by Baker (2012). 
Our research attempted to add another strategy to existing research and programs that are currently addressing gender issues in science education by investigating the differential effectiveness of the field-study classes for students of different genders.

\section{Research methods}

The study used a comparative research design in which two different types of learning environments were compared and contrasted: traditional environmental science classes; and field-study classrooms at the BNCEE. Students from schools visiting the BNCEE completed a questionnaire at lunchtime on the second day of their two-day session in order to provide comparative information about students' school-site classrooms and BNCEE in terms of learning environment and attitude criteria.

WIHIC and TOSRA questionnaires

In evaluating the effectiveness of field-study classrooms, we utilised questionnaire scales assessing both classroom learning environment and student attitudes to science. We assessed the learning environment with salient seven-item scales chosen from the What Is Happening In this Class? (WIHIC) questionnaire: Investigation (emphasis on the skills and processes of inquiry and their use in problem solving and investigation); Cooperation (extent to which it is important to complete activities planned and to stay on the subject matter); and Equity (extent to which students are treated equally by the teacher) (Aldridge, Fraser and Huang 1999).

Our study included students' attitudes to science as an important criterion in assessing the effectiveness of the field-study centre. We chose the Enjoyment of Science Lessons scale from the Test of Science Related Attitudes (TOSRA) (Fraser 1981) for assessing attitudes in our study. Because of time constraints, only seven of the ten questions in this scale were used. Negatively-worded items in the original TOSRA scale were omitted or reworded to avoid confusion among students.

The modified survey had a side-by-side response format. Next to the questions

there are two columns for responses, one for students to rate their traditional 
classroom and one for their perceptions of their field-study classroom. The response alternatives were altered slightly from those in the original WIHIC. The response alternatives in the original WIHIC are Almost Never, Seldom, Sometimes, Often and Almost Always. The Seldom response was changed to Rarely, a term better understood by fifth-grade students. In order to provide consistency between the WIHIC's and TOSRA's response formats, the same response alternatives were also used for the TOSRA scale. The items were scored as 1, 2, 3, 4 and 5, respectively, for these five response alternatives.

Content validation and pilot study

Once we had assembled our four-scale questionnaire for assessing the learning environment and attitudes among grade 5 students, we checked its content validity by seeking the assistance of six science teachers from the region and three science advisors/consultants from the local school district. These educators provided their opinions about the validity of questionnaire items for assessing the intended constructs and their suitability and readability for use among students in the target age group.

A pilot study, undertaken to check the suitability of the questionnaires for use in the main study, comprised the two phases of (1) analysis of the comprehensibility of questionnaires and (2) field testing of the questionnaire for reliability and validity of the survey. The comprehensibility of the questionnaire was explored with a small group of 25 students to check whether they understood the questions. The students were given approximately 30 minutes to complete the survey containing WIHIC and TOSRA scales. Once the survey had been completed, the 25 students were interviewed. In an attempt to include researcher triangulation, the researchers' assistants also conducted the short interviews.

The WIHIC and TOSRA scales were administered to 125 students during lunchtime on the second day of the two-day field study class. The main purpose of the field testing was to check whether modified versions of the WIHIC and TOSRA were valid and reliable when used with $5^{\text {th }}$ grade students in this unique field-study setting. No follow-up interviews were undertaken. The overall composition of the pilot sample responding to the survey reflected roughly the breakdown of the population of Miami-Dade County in terms of student race, ethnicity, culture and language 
proficiency. Each class was supervised by a teacher, parent or chaperone while a researcher administered the questionnaires. Once all the data were collected, statistical analyses were run to check the validity and reliability of the questionnaire.

The pilot study revealed three patterns. The modified WIHIC and TOSRA scales had satisfactory factorial validity and reliability. Second the instructions, questions, vocabulary and layout of the questionnaire were clear and easily understood by the majority of students interviewed. Third, the students interviewed did not feel pressured, pressed for time, nervous or distracted while answering the questionnaire. Therefore, we used the same questionnaire with confidence in the main study.

Sample for main study

The modified WIHIC and TOSRA scales were administered to 765 students during lunchtime on the second day of the two-day field study class. The overall composition of the student sample reflected roughly the breakdown of the population of MiamiDade County in terms of race, ethnicity, culture and language proficiency. According to 2004-2005 Florida Department of Education (FDOE) statistics, the racial/ethnic breakdown of the Miami-Dade County Public Schools (M-DCPS) is approximately $60 \%$ Hispanic, 28\% African-American, 8\% White, non-Hispanic and 4\% other. Therefore, the number of questionnaires administered approximately reflected this breakdown. Also, according to the FDOE (2004-2005), 9\% of the students enrolled in $5^{\text {th }}$ grade are considered LEP. The final breakdown of students who responded to our questionnaire was 418 females and 347 males. Among all students $(N=765)$ in 17 schools, the racial/ethnic breakdown was 411 Hispanic, 182 African-American, 61 White/non-Hispanic, and 56 Multiracial or other.

\section{Results}


The WIHIC, developed by Fraser, McRobbie and Fisher (1996), was modified for use with fifth graders, aged 9-13 years, for this study. Three of the seven original learning environment dimensions were utilised - Investigation, Cooperation and Equity - for both the home school science classes and BNCEE field-study classes. All seven items in each dimension were used, making a total of 21 questions. The Test of Science Related Attitudes (TOSRA), developed by Fraser (1981), was modified for use in this study. Because of time constraints, a modified seven-item version of only the Enjoyment of Science Lessons scale was used. A listing of the items in our questionnaire is provided in the Appendix.

To determine the factorial validity of the four WIHIC and TOSRA scales, principal axis factor analysis with varimax rotation and Kaiser normalisation was carried out. Separate factor analysis was conducted for the home school science classes and BNCEE field study-classes. The criteria for retention of any item were that its factor loading must be at least 0.40 on its own scale and less than 0.40 on each of the other three scales. A loading of 0.40 is a widely accepted cutoff value in factor analysis (Fraser, Aldridge and Soerjaningsih 2010; Quek, Wong and Fraser 2005).

Upon inspection of the first factor analysis, Item 11 from the Cooperation scale was removed as a result of a low factor loading for this item on its own scale. The remaining 27 items all had factor loading of at least 0.40 on their a priori scale and less than 0.40 on the three other scales for both home school science classes and BNCEE field-study classes. The factor analysis results are reported in Table 1.

\section{TABLE 1 ABOUT HERE}

The bottom of Table 1 shows that the percentage of variance ranged from $12.21 \%$ to $16.23 \%$ for different scales for home school science classes, with the total variance being $41.85 \%$, and from $10.75 \%$ to $13.63 \%$ for different scales for BNCEE fieldstudy classes, with the total variance being $35.20 \%$. The eigenvalue for home school classes and field-study classes, respectively, were 4.38 and 3.68 for Investigation, 3.62 and 2.92 for Cooperation, 3.30 and 2.90 for Equity, and 2.86 and 2.37 for Enjoyment of Science Lessons. Overall the results of the factor analysis shown in Table 1 support the factorial validity of the modified four-scale survey assessing learning environment and attitudes among the student sample of 765 students. 
The Cronbach alpha coefficient was calculated as an index of internal consistency for each of the three WIHIC scales and the TOSRA scale for the sample of 765 students separately for home school science classes and BNCEE field-study classes. The bottom of Table 1 reports the results of these analyses. The alpha coefficient for the different scales of the WIHIC ranged from 0.84 to 0.89 for home school classes and from 0.80 to 0.84 for field-study classes. The internal consistency reliability for the Enjoyment of Science Lessons scale was 0.92 for home school classes and 0.88 for field-study classes. Similar factor structures and internal consistency reliabilities for original and/or modified versions of the WIHIC were reported in validation studies in Canada (Zandvliet and Fraser 2004), Singapore (Chionh and Fraser 2009), Australia and Taiwan (Aldridge and Fraser 2000) and the U.S. (Allen and Fraser 2007; Wolf and Fraser 2008).

Overall effectiveness of BNCEE and differential effectiveness of BNCEE for students differing in sex and English proficiency

Our second research question involved whether BNCEE field-study classes were more effective than the home school classes in terms of the four learning environment and attitude scales. Our third research question focused on whether, in terms of learning environment and attitudes to science, BNCEE field study classes were differentially effective for males and females and for LEP and native English speakers. In order to answer these two research questions, we conducted a three-way MANOVA with repeated measures on one factor. The set of dependent variables consisted of the four learning environment and attitude scales (namely, Investigation, Cooperation, Equity and Attitudes). The instructional method (BNCEE field study classes or home school science classes) was the repeated-measure independent variable. The other two independent variables were student sex and English proficiency. The sample consisted of the same group of 765 students. For the purposes of the analysis, native English speakers were considered to have high English proficiency and LEP students were considered to have low English proficiency.

The BNCEE was considered to be differentially effective for students differing in English proficiency if the two-way interaction between instructional method and English proficiency turned out to be statistically significant. Similarly, the presence of a significant instruction $x$ sex interaction revealed that the BNCEE was differentially effective for male and female students. 
MANOVA yielded some statistically significant results overall, using Wilks' lambda criterion, for the set of four dependent variables. The instruction effect was statistically significant $(p<0.01)$ in the multivariate test. As well, both the English proficiency effect and the instruction $x$ English proficiency interaction were statistically significant. However the other main effect (sex) and the other two-way interaction effects (instruction $x$ sex, sex $x$ English proficiency, and the three-way instruction $x$ sex $x$ English proficiency) all were nonsignificant in the multivariate test.

\section{TABLE 2 ABOUT HERE}

Table 2 shows the corresponding univariate ANOVA results separately for each of the four dependent variables (Investigation, Cooperation, Equity, and Attitudes). Both statistical significance ( $F$ ratios) and effect sizes (the eta ${ }^{2}$ statistic, which represents the proportion of variance accounted for) are reported. The ANOVA results further illustrate the MANOVA results in that effects were statistically nonsignificant and effect sizes were tiny for all dependent variables for sex, sex $x$ English proficiency, instruction $x$ sex, and instruction $x$ sex $x$ English proficiency (with males' attitudes scores being slightly higher than females' attitude scores).

Table 2 shows statistical significance and large effect sizes for the instructional variable for all dependent variables (with very large effect sizes ranging from 0.44 to 0.56 of the variance), with higher scores for BNCEE than home school science. For English proficiency, differences were statistically significant but effect sizes were only modest in magnitude (ranging from eta ${ }^{2}=0.03$ to 0.06 ), with higher scores for native English speakers. However, the presence of statistically significant instruction $x$ English proficiency interactions with large effect sizes (ranging from eta ${ }^{2}=0.20$ to 0.23 for different dependent variables) means that it could be misleading to interpret either the instruction effect or the English proficiency effect independently of each other. Clearly, BNCEE was differentially effective for students differing in English proficiency. (However, Table 2 shows that the BNCEE was not differently effective for males and females as the instruction $x$ sex interaction was nonsignificant for every dependent variable). 
To further illuminate differences between the BNCEE and home school science classes in terms of students' perceptions of the learning environment and attitudes to science, the average item mean was calculated. Table 3 shows the average item mean and average item standard deviation for students in field-study classes and home school science classes for each of the three classroom environment scales and one attitude scale. This table indicates that scores were considerably higher for field-study classes than for the home school science classes in terms of learning environment and attitudes.

Table 3 also reports the effect size for the difference between home school science classes and field study classes for each learning environment and attitude scale. The effect size provides an index of the magnitude of effect, and is the difference between means expressed is standard deviation units. The effect size (Cohen's $d$ ) is calculated by dividing the difference between the two means by the pooled standard deviation. The effect size for the WIHIC scales ranged from 0.84 to 0.90 , and was 1.20 for the attitude scale. These effect sizes can be considered large (Cohen 1988).

\section{TABLE 4 ABOUT HERE}

In order to interpret the instruction $x$ English proficiency interactions, the average item mean for each learning environment and attitude scale is shown separately for BNCEE and home school classes and for native English speakers and LEP students in Table 4. This table also provides separately for native English speakers and LEP students the average item standard deviation and the magnitude of the difference between BNCEE and home school classes expressed as effect sizes (Cohen's $d$ or the number of standard deviations). Table 4 shows that the magnitudes of differences between BNCEE and home school classes were large for both LEP students and for native English speakers, but that these magnitudes are much larger for LEP students (with effect sizes ranging from 2.64 to 3.41 standard deviations) than for native English speakers (effect sizes ranging from 0.61 to 0.91 standard deviations). 
The interpretation of each of the four significant instruction $x$ English proficiency interactions is highly similar and is illustrated graphically in Figure 1 for one scale (namely, Investigation) which shows the average item mean for each of the four groups (BNCEE/native English speakers, BNCEE/LEP students, home school/native English speakers, home school/LEP students). Figure 1 shows that BNCEE classes were more effective than home school classes for students of both high and low English proficiency on all four criteria. But, relative to home school science classes, BNCEE classes were considerably more effective for LEP students than for students who are native English speakers.

\section{Discussion and conclusion}

This study further validated the What Is Happening In this Class (WIHIC) questionnaire for assessing informal classroom learning environments with a sample of 765 Grade 5 students (ages 9-13 years) at a field-study center. The WIHIC demonstrated satisfactory internal consistency reliability and factorial validity.

Once the validity of the WIHIC questionnaire was established, data were further analysed to answer another research question about the effectiveness of fieldstudy classes. Overall, BNCEE field-study classes were more effective than the home school science class in providing students with a more favourable learning environment where students can perform investigations, cooperate with other students and be treated equally with other students. As well, students' enjoyment of studying science was more positive in field study classes.

Our third research question involved the differential effectiveness of fieldstudy classes for students differing in sex and English proficiency. Analyses of the data suggested that the BNCEE Field Study Class was differentially effective for students differing in English proficiency. Relative to home school science classes, BNCEE was considerably more effective for LEP students than for students who are native English speakers.

This study had its limitations. Because the students who responded to the questionnaires did not attend the Biscayne Nature Center for Environmental Education (BNCEE) on a permanent basis, there were some logistical complications. 
On the first day of the two-day program, students were given a permission form informing parents and/or guardians of the intended research project and their children's possible participation in that project.

Another limitation of this study was the shortness of the instructional treatment. The students only stayed at the field-study centre for two days. If students had stayed longer, their attitudes towards science and perceptions of the learning environment perceptions might have changed further, thus altering the results of the study. In a future study of field-study classrooms, it is recommended that the questionnaires be administered to students who have attended more extensive fieldstudy classes. Because of time constraints and in attempt not to interfere with instructional time, the questionnaire (28 items) was short.

A limitation relates to the generalisability of results. Students from only 17 of the 222 elementary schools in Miami-Dade County Public Schools were sampled for this study. To enhance the generalisability of findings, students from more elementary schools should be encouraged to attend the field-study program and subsequently complete the questionnaires.

There were issues of potential researcher bias because one of the principal investigators was also a teacher at the BNCEE (and he could have made extraordinary efforts when teaching in the field so as to influence students to answer questionnaire items more favourably). Therefore, questionnaires were administered only to 735 students whom were not personally taught by this teacher/researcher.

During the study, students' behaviours might have been altered because they knew that they were being studied; this is called the Hawthorne effect (Franke \& Kaul, 1978). In a future study, and to minimise the Hawthorne effect, there are several steps that the researcher could take. First, researchers could inform the students' teachers to include the parental permission forms with the other forms required for the field trip. Secondly, the researcher could give all students some kind of activity to undertake during questionnaire administration. Children who brought a signed permission form could be given the questionnaire, whereas those without permission could be given some kind of post-field course assessment (e.g. a quiz or a reflective essay).

Although the methods of data analysis employed in our study were rigorous and adequate for our research purposes, all analysis methods have limitations and could have been supplemented by additional useful analyses. In particular, our 
exploratory factor analysis could have been supplemented by confirmatory factor analysis and our use of MANOVA could be supplemented by use of multilevel analysis.

The study was pioneering in that it explored differences between traditional classrooms and field-study classrooms in terms of students' perceptions of the learning environment. Few prior learning environments studies have addressed multidisciplinary science research and field-study classrooms. The side-by-side format of the questionnaire is also unique. One of the major aims of this study was to create a science learning environment questionnaire that would be suitable for $5^{\text {th }}$ grade, 9-13 year-old students. Because the questionnaire containing three WIHIC scales and one attitude scale was found to be valid and reliable, it could be used in further research (e.g. comparing traditional classrooms and non-traditional classrooms). The non-traditional classroom in this particular study happened to be a field-study, outdoor-education classroom. Other research in non-traditional classrooms, such as museums or aquariums, could use this type of assessment tool.

One of the most definitive statements in support of the National Science Education Standards (NSES) is that "the classroom is a limited environment, and the school science program must extend beyond the walls of the school to the resources of the community" (NRC, 1996, p. 45). According to the NSES, these include colleges, universities, parks, museums and nature centres. Our study further validated the NSES statement about the importance of field-study classrooms and programs for encouraging awareness of environmental issues and concerns in South Florida. The field-study classrooms frequently involved constructivist approaches, with a strong emphasis on 'hands-on' science education. Furthermore, we investigated whether field-study classrooms provide a positive and enjoyable learning environment for the study of environmental sciences.

Finally, our research investigated the differential effectiveness of field-study classes for LEP and native-English speakers, as well as for males and females. Handson science field-study classrooms were especially effective in promoting the learning environment and positive student attitudes towards science among students with limited English proficiency.

The findings of our research have several simple practical implications for science education. First, because we found that our field-study classrooms provided a positive and enjoyable learning environment, we recommend their more-frequent use in the teaching of environmental sciences. Second, in particular, we recommend the 
use of field-study centres especially among students with limited English proficiency because of their differential effectiveness with this subgroup of students. Finally, we recommend that others use our unique, economical and validated questionnaire for assessing learning environment and student attitudes in non-traditional out-of-school settings; this questionnaire is provided in the Appendix. 


\section{References}

Aldridge, J.M., \& Fraser, B.J. (2000). A cross-cultural study of classroom learning environments in Australia and Taiwan. Learning Environments Research, 3, 101-134.

Aldridge, J. M., \& Fraser, B. J. (2008). Outcomes-focused learning environments: Determinants and effects. Rotterdam, The Netherlands: Sense Publishers.

Aldridge, J.M., Fraser, B.J., \& Huang, T.C.I. (1999). Investigating classroom environments in Taiwan and Australia with multiple research methods. Journal of Educational Research, 93, 48-57.

Allen, D., \& Fraser, B.J. (2007). Parent and student perceptions of classroom learning environment and its association with student outcomes. Learning Environments Research, 10, 67-82.

Baird, D. (1997). Is the physics classroom any place for girls? The gender imbalance in physics education: How it came about and what teachers can do about it. Unpublished MS thesis, University of Michigan.

Baker, D.R. (2012). Equity issues in science education. In B.J. Fraser, K.G. Tobin and C.J. McRobbie (Eds.), Second international handbook of science education (pp. 869-895). New York: Springer.

Balling, J.D., \& Falk, J.H. (1980). A perspective on field trips: Environmental effects of learning. Curator, 23, 229-240.

Brickhouse, N. (1994). Bringing in the outsiders: Reshaping the sciences of the future. Journal of Curriculum Studies, 26, 401-416.

Bybee, R. (2001). Achieving scientific literacy: Strategies for insuring that free-choice science education complements national formal science education efforts. In J. H. Falk (Ed.), Free-choice science education: How do we learn outside of school (pp. 44-63). New York: Teachers College Press.

Chionh, Y. H., \& Fraser, B. J. (2009). Classroom environment, achievement, attitudes and selfesteem in geography and mathematics in Singapore. International Research in Geographical and Environmental Education, 18, 29-44.

Cohen, J. (1988). Statistical power analysis for the behavioral sciences. Hillsdale, NJ: Lawrence Erlbaum.

Cummins, J. (1984). Bilingualism and special education: Issues in assessment and pedagogy. Boston: College-Hill Press.

Cummins, J. (1986). Empowering minority students: A framework for intervention. Harvard Educational Review, 56, 18-35. 
Cuevas, P., Lee, O., Hart, J., \& Deaktor, R. (2005). Improving science inquiry with elementary students of diverse backgrounds. Journal of Research in Science Teaching, 42, 337-357.

Dhingra, K. (2003). Thinking about television science: How students understand the nature of science from different program genres. Journal of Research in Science Teaching, 40, 234256.

Dorman, J.P. (2003). Cross-national validation of the What Is Happening In this Class? (WIHIC) questionnaire using confirmatory factor analysis. Learning Environments Research, 61, 231-245.

Dorman, J. P. (2008). Use of multitrait-multimethod modelling to validate actual and preferred forms of the What Is Happening In this Class? (WIHIC) questionnaire. Learning Environments Research, 11, 179-197.

Falk, J.H. (1983). A cross-cultural investigation of the novel field trip phenomenon: National museum of natural history. Curator, 26, 315-325.

Falk, J.H. (2001). Free-choice science learning: Framing the discussion. In J.H. Falk (Ed.), Freechoice science education: How do we learn science outside of school (pp. 3-20). New York: Teachers College Press, New York.

Falk, J.H., \& Adelman, L.M. (2003). Investigating the impact of prior knowledge and interest on aquarium visitor learning. Journal of Research in Science Teaching, 40, 163-176.

Falk, J.H., \& Balling, J.D. (1982). The field trip milieu: Learning and behavior as a function of contextual events. Journal of Educational Resources, 76, 22-28.

Falk, J.H., \& Dierking, L.D. (2002). Lessons without limits: How free-choice learning is transforming education. Lanham, MD: Rowman \& Littlefield Publishers, Inc.

Falk, J.H., \& Dierking, L.D. (2012). Lifelong science learning for adults: The role of free-choice experiences. In B.J. Fraser, K.G. Tobin and C.J. McRobbie (Eds.), Second international handbook of science education (pp. 1063-1079). New York: Springer.

Falk, J.H., Martin, W.W., \& Bailing, J.D. (1978). The novel field-trip phenomena: Adjustment to novel settings interferes with task learning. Journal of Research in Science Teaching, $15,127-134$.

Fido, S.H., \& Gayford, G.C. (1982). Field work and the biology teacher: A survey in secondary schools in England and Wales. Journal of Biological Education, 16, 27-34.

Fisher, D.L., \& Khine, M.S. (2006). Contemporary approaches to research on learning environments: Worldviews. Singapore: World Scientific.

Fleishman, H.L., \& Hopstock, P.J. (1993). Descriptive study of services to limited English proficient students: Volume 1: Summary of findings and conclusions. Arlington, VA: Development Associates, Inc.

Fradd, S.H., \& Lee, O. (1999). Teachers' roles in promoting science inquiry with students from diverse languages backgrounds. Educational Researcher, 28, 4-20, 42. 
Franke, R.H., \& Kaul, J.D. (1978). The Hawthorne effect: First statistical interpretation. American Sociological Review, 43, 623-643.

Fraser, B.J. (1978). Development of a test of science-related attitudes. Science Education, 62, 509-515.

Fraser, B.J. (1981). Test of Science-Related Attitudes. Melbourne, Australia: Australian Council for Educational Research.

Fraser, B. J. (1986). Classroom environment. London: Croom Helm.

Fraser, B.J. (1990). Individualised Classroom Environment Questionnaire (ICEQ). Melbourne: Australian Council for Educational Research.

Fraser B.J. (1998a). Classroom environment instruments: Development, validity and applications. Learning Environments Research, 1, 7-33.

Fraser, B.J. (1998b). Science learning environments: Assessment, effects and determinants. In B.J. Fraser \& K.G. Tobin (Eds.), International handbook of science education (pp. 527-564). Dordrecht, The Netherlands: Kluwer Academic Publishers.

Fraser, B. J. (2012). Classroom learning environments: Retrospect, context and prospect. In B.J. Fraser, K.G. Tobin and C.J. McRobbie (Eds.), Second international handbook of science education (pp. 1191-1239. New York: Springer.

Fraser, B. J. (2014). Classroom learning environments: Historical and contemporary perspectives. In N.G. Lederman and S.K. Abell (Eds.), Handbook of research on science education (pp. 104-119. New York: Routledge.

Fraser, B.J., Aldridge, J.M., \& Adolphe, F.S.G. (2010). A cross-national study of secondary science classroom environments in Australia and Indonesia. Research in Science Education, 40, 551-571.

Fraser, B. J., Aldridge, J. M., \& Soerjaningsih, W. (2010). Instructor-student interpersonal interaction and student outcomes at the university level in Indonesia. The Open Education Journal, 3, 21-33.

Fraser, B.J., Butts, W.L. (1982). Relationship between perceived levels of classroom individualization and science-related attitudes. Journal of Research in Science Teaching, 19, 143-154.

Fraser, B.J., Fisher, D.L., \& McRobbie, C.J. (1996, April). Development, validation and use of personal and class forms of a new classroom environment instrument. Paper presented the annual meeting of the American Educational Research Association, New York.

Fraser, B.J., Giddings, G.J., \& McRobbie, C.J. (1995). Evolution and validation of a personal form of an instrument for assessing science laboratory classroom environments. Journal of Research in Science Teaching, 32, 399-422. 
Fraser, B.J., \& McRobbie, C.J. (1995). Science laboratory classroom environments at schools and universities: A cross-national study. Educational Research and Evaluation, 1, 289317.

Fraser, B.J., McRobbie, C.J., \& Giddings, G.J. (1993). Development and cross-national validation of a laboratory classroom environment instrument for senior high school science. Science Education, 77, 1-24.

Fraser, B. J., \& Raaflaub C. (2013). Subject and sex differences in the learning environment Perceptions and attitudes of Canadian mathematics and science students using laptop computers. Curriculum and Teaching, 28 (1), 57-78.

Fraser, B.J., \& Walberg, H.J. (Eds.). (1991). Educational environments: Evaluation, antecedents and consequences. London: Pergamon Press.

Harington, D.G. (2001). The development and validation of a learning environment instrument for CSIRO Science Education Centers. Unpublished Doctor of Science Education thesis, Curtin University of Technology.

Helding, K. A., \& Fraser, B. J. (2013). Effectiveness of National Board Certification (NBC) teachers in terms of classroom environment, attitudes and achievement among secondary science students. Learning Environments Research, 13, 1-21.

Hofstein, A., Bybee, R.W., \& Legro, P.L. (1997). Linking formal and informal science education through science education standards. Science Education International, 8, 31-37.

Hofstein, A., \& Rosenfeld, S. (1996). Bridging the gap between formal and informal science learning. Studies in Science Education, 28, 87-112.

Kahle, J.B., \& Lakes, M. (1983). The myth of equality in science classrooms. Journal of Research in Science Teaching, 20, 131-140.

Kelly, A. (1987). Science for girls. Milton Keynes, UK: Open University Press.

Khine, M. S., \& Fisher, D. L. (Eds.). (2003). Technology-rich learning environments: A future prespective. Singapore: World Scientific.

Khoo, H.S., \& Fraser, B.J. (2008). Using classroom psychosocial environment in the evaluation of adult application course in Singapore. Technology, Pedagogy and Education, 17, 53-67.

Kim, H.-B., Fisher, D.L., \& Fraser, B.J. (2000). Classroom environment and teacher interpersonal behavior in secondary science classes is Korea. Evaluation and Research in Education, 14, 3-22.

Kind, P.M., Jones, K., \& Barmby, P. (2007). Developing attitudes towards science measures. International Journal of Science Education, 29, 871-893.

Koh, N.K., \& Fraser, B.J. (2014). Learning environment associated with use of mixed mode delivery model among secondary business studies students in Singapore. Learning Environments Research, 17, 157-171. 
Koul, R. K., \& Fisher, D. L. (2004). Students' perception of science learning environments in Jammu: Attitudes and gender differences. Indian Journal of Science Communication, 3, 16-25.

Kubota, C. A., \& Olstad, R. G. (1991). Effects of novelty-reducing preparation on exploratory behavior and cognitive learning in a science museum setting. Journal of Research in Science Teaching, 28, 225-234.

Lee, O. (2002). Science inquiry for elementary students from diverse backgrounds. In W.G. Secada (Ed.), Review of research in education (Vol. 26, pp. 23-69). Washington, DC: American Educational Research Association.

Lee, O., \& Avalos, M.A. (2002). Promoting science instruction and assessment for English language learners. Electronic Journal of Science Education (online).http://ejse.southwestern.edu/original\%20site/manuscripts/v7n2/articles/art03_ lee/LEE.PDF (date retrieved: October 8, 2007).

Lightburn, M. E., \& Fraser B. J. (2007). Classroom environment and student outcomes among students using anthropometry activities in high school: science. Research in Science and Technological Education, 25, 153-166.

Long, C., \& Fraser, B.J. (2015). Comparison of alternative sequencing of middle-school science curriculum: Classroom learning environment and student attitudes. Curriculum $\mathcal{E}$ Teaching, 30, 23-36.

Martin, W.W., Falk, J.H., \& Balling, J.D. (1981). Environmental effects on learning: The outdoor field trip. Science Education, 65, 301-309.

Martin-Dunlop, C.S., \& Fraser, B.J. (2008). Learning environment and attitudes associated with an innovative science course designed for prospective elementary teachers. International Journal of Science and Mathematics Education, 6, 193-198.

McKenzie, G., Utgard, R., \& Lisowski, M. (1986). The importance of field trip: A geological example. Journal of College Science Teaching, 16, 17-20.

Moos, R.H. \& Trickett, E.J. (1974). Classroom Environment Scale manual. Palo Alto, CA: Consulting Psychologists Press.

National Research Council. (1996). National Science Education Standards. Washington, DC: National Academy of Science.

Nix, R.K., Fraser, B.J., \& Ledbetter, C.Y. (2005). Evaluating an integrated science learning environment using the Constructivist Learning Environment Survey. Learning Environments Research, 8, 109-133.

Orion, N., \& Hofstein, A. (1994). Factors that influence learning during scientific trip in a natural environment. Journal of Research in Science Teaching, 31, 1097-1119. 
Orion, N., Hofstein, A., Tamir, P., \& Giddings, G.L. (1997). Development and validation of an instrument for assessing the learning environment of outdoor science activities. Science Education, 81, 161-171.

Osborne, J., Simon, S., \& Collins, S. (2003). Attitudes towards science: A review of the literature and its implications. International Journal of Science Education, 25, 1049-1079.

Parker, L.H., Rennie, L.J., \& Fraser, B.J. (Eds.). (1996). Gender, science and mathematics: Shortening the shadow. Dordrecht, the Netherlands: Kluwer.

Price, S., \& Hein, G.E. (1991). More than a field trip: Science programs for elementary school groups at museums. International Journal of Science Education, 13, 505-519.

Quek, C.L., Wong, A.F.L., \& Fraser, B.J. (2005). Student perceptions of chemistry laboratory learning environments, student-teacher interactions and attitudes in secondary school gifted education classes in Singapore. Research in Science Education, 35, 299-321.

Rich, W.C. (2004). Design attributes of educational computer software for optimizing girls' participation in educational game playing. Unpublished PhD thesis, Curtin University of Technology, Perth, Australia.

Rickards, T., den Brok, P., Bull, E., \& Fisher, D. (2003, August). Predicting student views of the classroom: A California perspective. Proceedings of Western Australian Institute for Educational Research Forum 2003.

Rosebery, A.S., Warren, B., \& Conant, F.R. (1992). Appropriating scientific discourse: Findings from language minority classrooms. The Journal of the Learning Sciences, 2, 61-94.

Scarcella, R. (2003). Academic English: A conceptual framework (Technical Rep. 2003-1). Santa Barbara, CA: University of California Linguistic Minority Research Institute.

Schriesheim, C.A., \& Eisenbach, R.J., \& Hill, K.D. (1991). The effect of negation and polar opposite item reversals on questionnaire reliability and validity: An experimental investigation. Educational and Psychological Measurement, 51, 67-78.

Schwedes, H. (n.d.). Gender bias in science and science education. (online) http://www.physik.unibremen.de/physics.education/schwedes/text/bellater.htm (date retrieved: August 17, 2006).

Shroyer, M., Backe, K., \& Powell, J. (1995). Developing a science curriculum that addresses the learning preferences of male and female middle level students. In D. Baker, \& K. Scantlebury (Eds.), Science "coeducation": Viewpoints from gender, race and ethnic perspectives (NARST monograph, Number 7) (pp. 88-108). Columbus: OH: National Association for Research in Science Teaching.

Soper, R.B. (2009). Informal science learning environments: Assessment, determinants and effects. Unpublished PhD thesis, Curtin University of Technology.

Taylor, P.C., Fraser, B.J., \& Fisher, D.L. (1997). Monitoring constructivist classroom learning environments. International Journal of Educational Research, 27, 293-302. 
Thomas, W.P., \& Collier, V.P (2001). A national study of school effectiveness for language minority students' long-term academic achievement (Final Report: Project 1.1). (online) http://crede.berkeley.edu/research/llaa/1.1 final.html. (date retrieved August 21, 2006).

Tytler, R., \& Osborne, J. (2012). Student attitudes and aspirations towards science. In B.J. Fraser, K.G. Tobin and C.J. McRobbie (Eds.), Second international handbook of science education (pp. 597-625). New York: Springer.

Walberg, H.J., \& Anderson, G.J. (1968). Classroom climate and individual learning. Journal of Educational Psychology, 59, 414-419.

Warren, B., Ballenger, C., Ogonowski, M. Rosebery, A., \& Hudicourt-Barnes, J. (2001a). Rethinking diversity in learning science: The logic of everyday sense-making. Journal for Research in Science Teaching, 38, 529 - 552.

Warren, B., Ballenger, C., Ogonowski, M. Rosebery, A., \& Hudicourt-Barnes, J. (2001b). Rethinking diversity in learning science: The logic of everyday language. Journal of Research in Science Teaching, 39, 579-605.

Wellington, J. (1990). Formal and informal learning in science: The role of the interactive centres. Physics Education, 25, 247-252.

Wolf, S.J., \& Fraser, B.J. (2008). Learning environment, attitudes and achievement among middle-school science students using inquiry-based laboratory activities. Research in Science Education, 38, 321-241.

Wong, A.L.F., \& Fraser, B.J. (1996). Environment-attitude associations in chemistry laboratory classroom. Research in Science \& Technological Education, 14, 91-102.

Wubbels, T., \& Brekelmans, M. (2005). Two decades of research on teacher-student relationships in class. International Journal of Educational Research, 43, 6-24.

Wubbels, T., \& Brekelmans, M. (2012). Teacher-student relationships in the classroom. In B.J. Fraser, K.G. Tobin and C.J. McRobbie, (Eds.), Second international handbook of science education (pp. 1241-1255). New York: Springer.

Wubbels, T., \& Levy, J. (Eds.). (1993). Do you know what you look like: Interpersonal relationships in education. London, England: Falmer Press.

Zandvliet, D.B., \& Fraser, B.J. (2004). Learning environments in information and communications technology classrooms. Technology, Pedagogy and Education, 13, 97123.

Zandvliet, D.B., \& Fraser, B.J. (2005). Physical and psychosocial environments associated with networked classrooms. Learning Environments Research, 8, 1-17.

Zinicola, D., \& Devlin-Scherer, R. (2001). A university-museum partnership for teacher education field experiences in science. The Clearing House, 74, 248-250. 


\section{List of figures}

Fig. 1 Interactions between instruction (BNCEE and home school science) and student English proficiency for four learning environment and enjoyment scales 

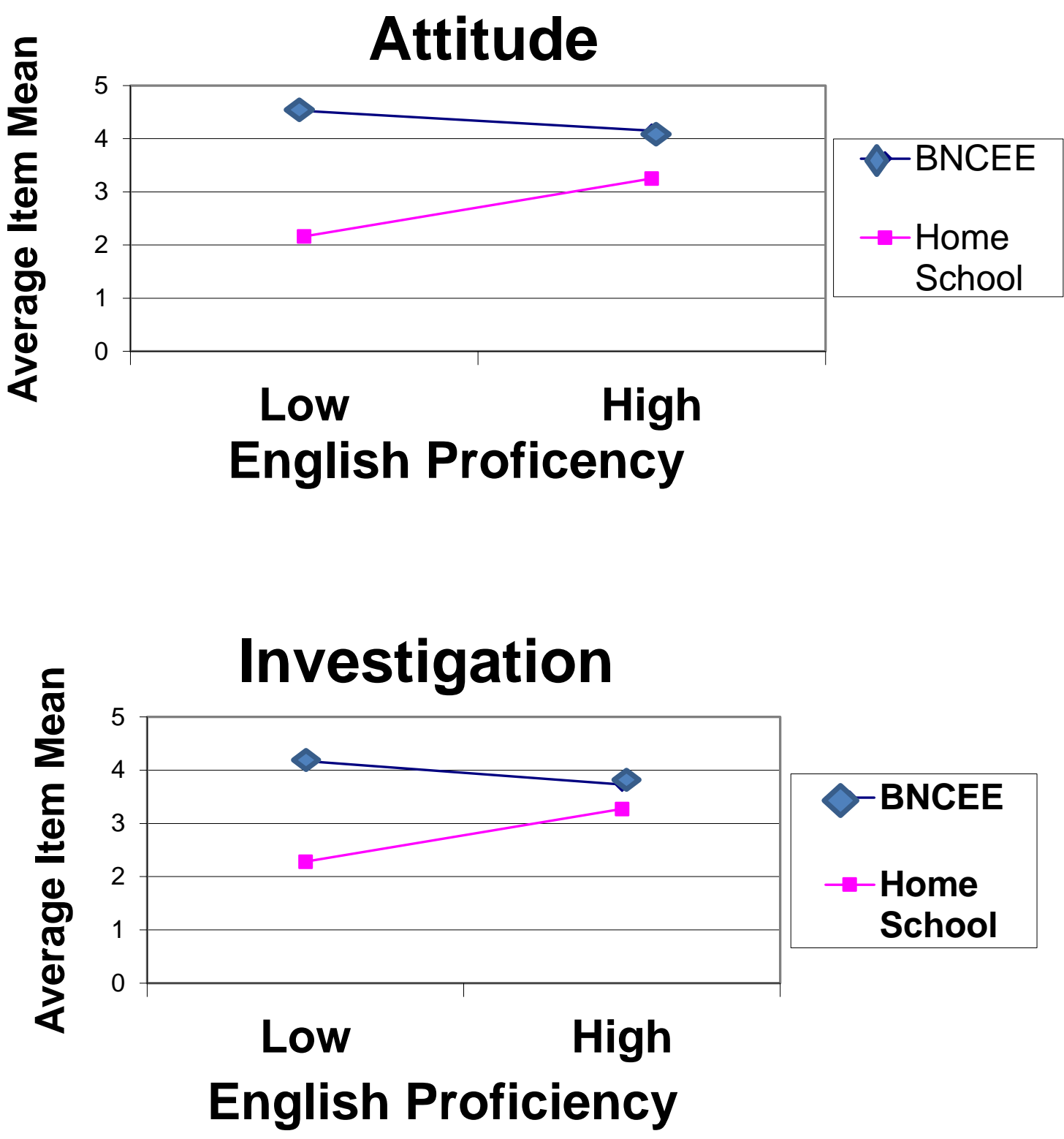

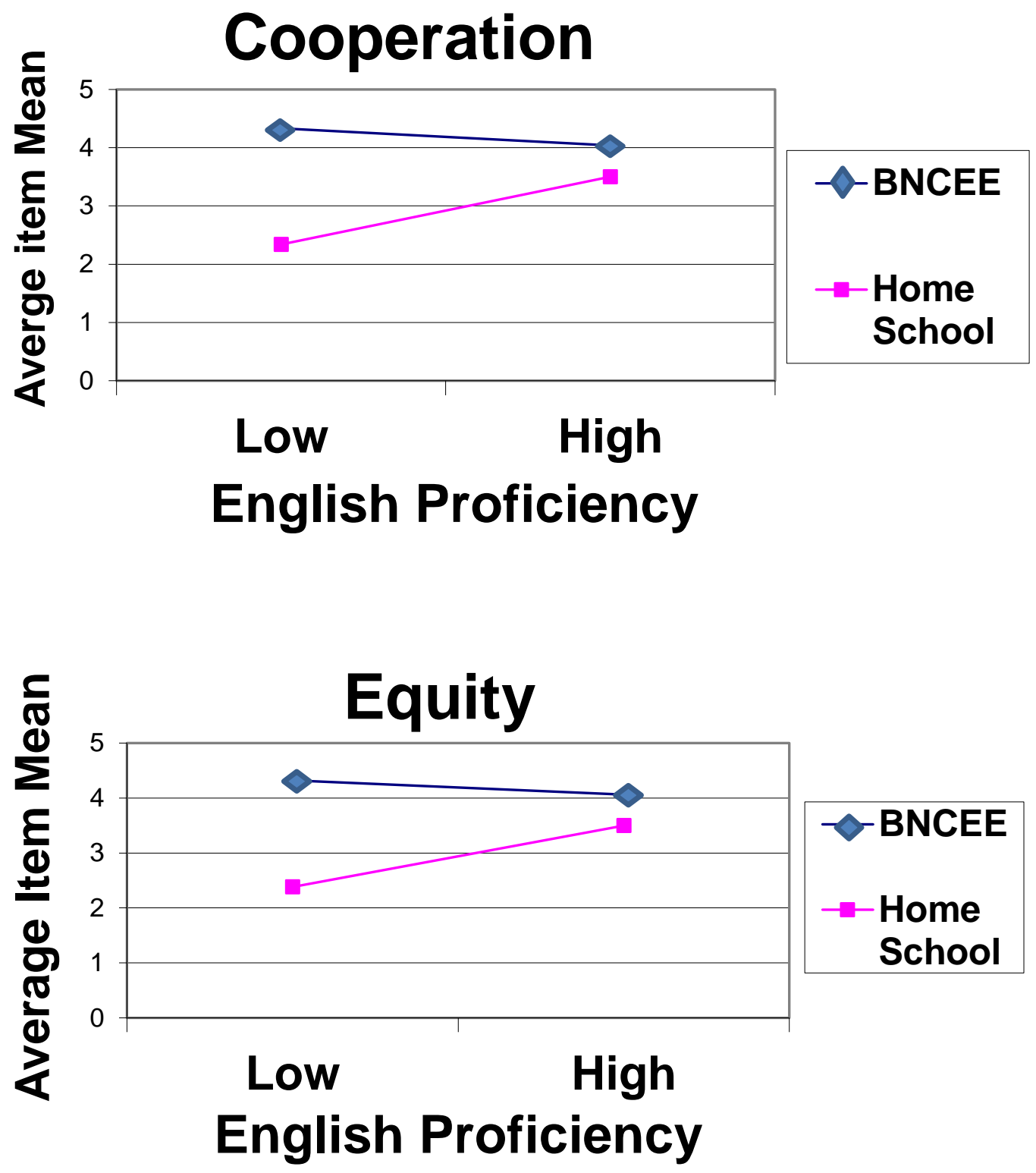

Fig. 1 
Table 1 Factor analysis results and alpha reliability for the modified WIHIC and TOSRA scales for home school science classes and BNCEE Field-Study Classes

\begin{tabular}{|c|c|c|c|c|c|c|c|c|}
\hline \multirow[b]{3}{*}{ Item No. } & \multicolumn{8}{|c|}{ Factor Loadings } \\
\hline & \multicolumn{2}{|c|}{ Investigation } & \multicolumn{2}{|c|}{ Cooperation } & \multicolumn{2}{|c|}{ Equity } & \multicolumn{2}{|c|}{ Enjoyment } \\
\hline & $\begin{array}{l}\text { Home } \\
\text { school } \\
\text { science }\end{array}$ & $\begin{array}{c}\text { BNCEE } \\
\text { field } \\
\text { study }\end{array}$ & $\begin{array}{l}\text { Home } \\
\text { school } \\
\text { science }\end{array}$ & $\begin{array}{c}\text { BNCEE } \\
\text { field } \\
\text { study }\end{array}$ & $\begin{array}{l}\text { Home } \\
\text { school } \\
\text { science }\end{array}$ & $\begin{array}{c}\text { BNCEE } \\
\text { field } \\
\text { study }\end{array}$ & $\begin{array}{l}\text { Home } \\
\text { school } \\
\text { science }\end{array}$ & $\begin{array}{c}\text { BNCEE } \\
\text { field } \\
\text { study }\end{array}$ \\
\hline 1 & 0.51 & 0.47 & & & & & & \\
\hline 2 & 0.44 & 0.48 & & & & & & \\
\hline 3 & 0.62 & 0.68 & & & & & & \\
\hline 4 & 0.44 & 0.57 & & & & & & \\
\hline 5 & 0.52 & 0.51 & & & & & & \\
\hline 6 & 0.53 & 0.58 & & & & & & \\
\hline 7 & 0.49 & 0.47 & & & & & & \\
\hline 8 & & & 0.66 & 0.52 & & & & \\
\hline 9 & & & 0.59 & 0.68 & & & & \\
\hline 10 & & & 0.53 & 0.47 & & & & \\
\hline 12 & & & 0.62 & 0.50 & & & & \\
\hline 13 & & & 0.61 & 0.53 & & & & \\
\hline 14 & & & 0.47 & 0.46 & & & & \\
\hline 15 & & & & & 0.52 & 0.50 & & \\
\hline 16 & & & & & 0.61 & 0.60 & & \\
\hline 17 & & & & & 0.61 & 0.57 & & \\
\hline 18 & & & & & 0.64 & 0.57 & & \\
\hline 19 & & & & & 0.61 & 0.53 & & \\
\hline 20 & & & & & 0.59 & 0.58 & & \\
\hline 21 & & & & & 0.58 & 0.49 & & \\
\hline 22 & & & & & & & 0.64 & 0.57 \\
\hline 23 & & & & & & & 0.71 & 0.67 \\
\hline 24 & & & & & & & 0.64 & 0.66 \\
\hline 25 & & & & & & & 0.69 & 0.71 \\
\hline 26 & & & & & & & 0.76 & 0.70 \\
\hline 27 & & & & & & & 0.64 & 0.63 \\
\hline 28 & & & & & & & 0.75 & 0.63 \\
\hline$\%$ Variance & 16.23 & 13.63 & 13.41 & 10.82 & 12.21 & 10.75 & 10.60 & 8.78 \\
\hline Eigenvalue & 4.38 & 3.68 & 3.62 & 2.92 & 3.30 & 2.90 & 2.86 & 2.37 \\
\hline$\alpha$ Reliability & 0.84 & 0.81 & 0.87 & 0.80 & 0.89 & 0.84 & 0.92 & 0.88 \\
\hline
\end{tabular}

Factor loadings less than 0.4 omitted from table.

Item 11 was omitted from the Cooperation scale. 
Table 2 MANOVA/ANOVA results $\left(F\right.$ and $\left.E^{2}{ }^{2}\right)$ for instruction, sex and English-proficiency differences in learning environment and enjoyment scales

\begin{tabular}{|c|c|c|c|c|c|c|c|c|}
\hline \multirow[t]{2}{*}{ Effect } & \multicolumn{2}{|c|}{ Investigation } & \multicolumn{2}{|c|}{ Cooperation } & \multicolumn{2}{|c|}{ Equity } & \multicolumn{2}{|c|}{ Enjoyment } \\
\hline & $F$ & Eta $^{2}$ & $F$ & $E t^{2}$ & $F$ & $\mathrm{Eta}^{2}$ & $F$ & $\mathrm{Eta}^{2}$ \\
\hline Instruction & $57.18^{* *}$ & 0.44 & $68.44^{* *}$ & 0.47 & $63.43^{* *}$ & 0.47 & $95.97^{* *}$ & 0.56 \\
\hline English Proficiency & $21.35^{* *}$ & 0.03 & $45.79^{* *}$ & 0.06 & $44.95^{* *}$ & 0.06 & $26.62^{* *}$ & 0.03 \\
\hline Sex & 2.10 & 0.00 & 2.16 & 0.00 & 2.94 & 0.00 & $5.01^{*}$ & 0.01 \\
\hline $\begin{array}{l}\text { Instruction x English } \\
\text { Proficiency }\end{array}$ & $24.09^{* *}$ & 0.23 & $21.09^{* *}$ & 0.23 & $24.74^{* *}$ & 0.21 & $12.75^{* *}$ & 0.20 \\
\hline $\begin{array}{l}\text { Sex } x \text { English } \\
\text { Proficiency }\end{array}$ & 0.06 & 0.00 & 0.57 & 0.00 & 0.01 & 0.00 & 0.00 & 0.00 \\
\hline Instruction $x$ Sex & 0.44 & 0.00 & 1.30 & 0.00 & 0.02 & 0.00 & 0.50 & 0.00 \\
\hline $\begin{array}{l}\text { Instruction x Sex x } \\
\text { English Proficiency }\end{array}$ & 0.02 & 0.00 & 1.55 & 0.00 & 0.54 & 0.00 & 0.62 & 0.00 \\
\hline
\end{tabular}

${ }^{*} p<0.05,{ }^{* *} p<0.01$

The eta ${ }^{2}$ statistic represents the proportion of variance explained by class membership. 
Table 3 Average item mean, average item standard deviation and difference (effect size and MANOVA results) between BNCEE field-study classes and home school science classes in learning environment and enjoyment scales

\begin{tabular}{lcccccc}
\hline Scale & \multicolumn{2}{c}{ Average item mean } & \multicolumn{2}{c}{ Average item SD } & \multicolumn{2}{c}{ Difference } \\
\cline { 2 - 7 } & $\begin{array}{l}\text { Home } \\
\text { school } \\
\text { science }\end{array}$ & $\begin{array}{c}\text { BNCEE } \\
\text { field study }\end{array}$ & $\begin{array}{c}\text { Home } \\
\text { school } \\
\text { science }\end{array}$ & $\begin{array}{c}\text { BNCEE } \\
\text { field study }\end{array}$ & $\begin{array}{c}\text { Effect size } \\
d\end{array}$ & $F$ \\
\hline Investigation & 3.08 & 3.81 & 0.92 & 0.82 & 0.84 & $4.15^{* *}$ \\
Cooperation & 3.28 & 4.10 & 1.04 & 0.77 & 0.90 & $4.36^{* *}$ \\
Equity & 3.28 & 4.11 & 1.06 & 0.77 & 0.90 & $4.42^{* *}$ \\
Enjoyment & 3.04 & 4.22 & 1.12 & 0.83 & 1.20 & $5.07^{* *}$ \\
\hline$* * 0<01$ & & & & & &
\end{tabular}

$(N=765)$

Effect size $($ Cohen's $d)=($ Mean $1-$ Mean2 $) / S_{\text {pooled }}$ 
Table 4 Average item mean, average item standard deviation, and difference between BNCEE and home school classes (effect size) for native English speakers and LEP students for learning environment and Enjoyment scales

\begin{tabular}{|c|c|c|c|c|c|c|}
\hline \multirow[t]{2}{*}{ Scale } & \multirow[t]{2}{*}{ English Proficiency } & \multicolumn{2}{|c|}{ BNCEE Field Study Class } & \multicolumn{2}{|c|}{ Home School Science } & \multirow{2}{*}{$\begin{array}{l}\text { Difference } \\
\text { Effect Size }\end{array}$} \\
\hline & & Mean & $\mathrm{SD}$ & Mean & $\mathrm{SD}$ & \\
\hline \multirow[t]{2}{*}{ Investigation } & Native speaker & 3.73 & 0.83 & 3.27 & 0.84 & 0.90 \\
\hline & LEP & 4.17 & 0.66 & 2.28 & 0.77 & 2.64 \\
\hline \multirow[t]{2}{*}{ Cooperation } & Native speaker & 4.04 & 0.80 & 3.50 & 0.97 & 0.61 \\
\hline & LEP & 4.33 & 0.58 & 2.34 & 0.80 & 2.85 \\
\hline \multirow[t]{2}{*}{ Equity } & Native speaker & 4.06 & 0.80 & 3.50 & 1.00 & 0.62 \\
\hline & LEP & 4.32 & 0.59 & 2.38 & 0.80 & 2.76 \\
\hline \multirow[t]{2}{*}{ Enjoyment } & Native speaker & 4.15 & 0.87 & 3.25 & 1.09 & 0.91 \\
\hline & LEP & 4.52 & 0.58 & 2.16 & 0.79 & 3.41 \\
\hline
\end{tabular}

$N=617$ native English speakers and 148 LEP students

Effect size $($ Cohen's $d)=($ Mean $1-$ Mean2 $) / S_{\text {pooled }}$ 


\section{Appendix}

\section{Listing of Learning Environment and Attitude Items}

\section{Investigation}

1. I carry out experiments to test my ideas.

2. I am asked to think about what happened in my experiment.

3. I carry out investigations to answer questions coming from discussions.

4. I explain the meaning of statements, diagrams, and graphs.

5. I carry out investigations to answer questions that puzzle me.

6. I carry out investigations to answer the teacher's questions.

7. I find out more answers to questions by doing investigations.

\section{Cooperation}

8. I cooperate with other students when doing assignment work.

9. When I work in groups in this class, there is teamwork.

10. I work with other students on projects in this class.

11. I learn from other students in this class.

12. I work with other students in this class.

13. I cooperate with other students on class activities.

14. Students work with me to achieve class goals.

\section{Equity}

15. The teacher gives as much attention to my questions as to other students' questions.

16. I get the same amount of help from the teacher as do other students.

17. I am treated the same as other students in this class.

18. I receive the same encouragement from the teacher as other students do.

19. I get the same opportunity to contribute to class discussions as other students.

20. My work receives as much praise as other students' work.

21. I get the same opportunity to answer questions as other students.

\section{Enjoyment}

22. Science lessons are fun.

23. I like science lessons.

24. School should have more science lessons each week.

25. Science is one of the most interesting school subjects.

26. I enjoy going to science lessons.

27. The material covered in science lessons is interesting.

28. I look forward to science lessons. 